\title{
NON-APOLOGY IN THE AGE OF APOLOGY
}

\author{
Aliza Gail Organick*
}

'The past is never dead. It's not even past'.

\section{INTRODUCTION}

After more than two decades winding its way through a variety of United Nations (UN) mechanisms, in September 2007 the world's indigenous peoples welcomed the news that the UN Declaration on the Rights of Indigenous Peoples (hereinafter the Declaration) was at last approved by the vast majority of nation-states. ${ }^{2}$ The four settler ${ }^{3}$ states that opposed the Declaration initially (the United States, Canada, Australia and New Zealand) have each in turn voiced their ultimate approval of the declaration and have issued statements in support to their indigenous citizens.

In spite of the fact that these statements expressed a measure of regret for past wrongs committed, not one of those endorsements embodied a formal apology. Now that the Declaration has entered its eleventh year, many continue to question to what extent these endorsements have meaningfully advanced reconciliation for indigenous peoples and whether these endorsements were authentic in their stated desire to do more than just acknowledge the aspirations contained in the Declaration.

This comment will examine the framework for political apologies in general and then consider the endorsements of the Declaration by the United States, Canada, Australia and New Zealand in light of contemporary apology theory. The article will then examine affirmative actions taken by those states following their endorsements in order to advance the claims of indigenous peoples and look at whether these actions have fallen short in providing meaningful redress for centuries of past wrongs.

\footnotetext{
* Weihofen Professor of Law, University of New Mexico School of Law.

1 William Faulkner, Requiem for a Nun (first published 1950, Vintage Books 2011) 73.

2 United Nations Department of Economic and Social Affairs, Indigenous Peoples

(United Nations, 2016) <https://www.un.org/development/desa/indigenouspeoples/ declaration-on-the-rights-of-indigenous-peoples.html> accessed 5 August 2019.

${ }^{3}$ I use the term settler nations to describe the colonial occupations of indigenous homelands by those who came with intent to remain.
} 


\section{NECESSARY ELEMENTS OF APOLOGY}

\section{The Interpersonal Apology}

Apologies occur in many contexts from interpersonal relationships to international relations. Regardless of the context, there is consensus that in order for an apology to be effective, there are several elements that must be met to achieve the desired outcome. ${ }^{4}$ Researchers posit that the 'best' apologies include: (1) an expression of regret; (2) an explanation of what went wrong; (3) an acknowledgement of responsibility; (4) a declaration of repentance; (5) an offer of repair; and (6) a request for forgiveness. ${ }^{5}$

Researchers are quick to point out that not all elements of any apology have equal weight. ${ }^{6}$ The most significant component of an apology is the taking of responsibility, with the offer of repair being second in importance. ${ }^{7}$ The request for forgiveness ${ }^{8}$ was ranked as the least valuable component. ${ }^{9}$ Studies have also shown that apologies that occur long after the wrong was incurred risk being seen as disingenuous or made for political gain rather than from a place of moral good. ${ }^{10}$

Most of us know a good apology when we hear it. We also know when an apology seems qualified in a way that undermines its effectiveness. According to psychologist Dr Harriet Lerner, a 'true' apology must fulfil nine essential rules. ${ }^{11}$

${ }^{4}$ Roy Lewicki and others, 'An Exploration of the Structure of Effective Apologies' (2016) 9(2) Negotiation and Conflict Management Research 177, 178-179.

5 Jeff Grabmeier, 'The 6 Elements of an Effective Apology, According to Science' (The Ohio State University, 12 April 2018) <https://news.osu.edu/the-6-elements-of-aneffective-apology-according-to-science/> accessed 19 November 2018.

${ }^{6}$ Ibid.

7 Ibid.

8 Ibid.

${ }^{9}$ Ibid.

${ }^{10}$ Elizabeth Hopper, 'What Makes a Political Apology Seem Sincere?' (Greater Good Magazine, 2 August 2017) <https://greatergood.berkeley.edu/article/item/what_makes_a_ political_apology_seem_sincere> accessed 24 April 2019.

${ }^{11}$ Harriet Lerner PhD, 'The 9 Rules for True Apologies' (Psychology Today, 14 September 2014) $<$ https://www.psychologytoday.com/us/blog/the-dance-connection/ 201409/the-9-rules-true-apologies> accessed 7 November 2018. The nine rules for a true apology according to Lerner: (1) Does not include the word 'but'; (2) Keeps the focus on actions of the person apologising; (3) Does not overshadow the feelings of the hurt party with the hurt or remorse of the person making the apology; (4) Does not 'get caught up' in blame; (5) Must have corrective action; (6) Avoids repeating harmful actions; (7) Should 
In the context of this article, three of those rules in particular have significance. Dr Lerner asserts that a true apology must be followed up with 'corrective actions, requires meaningful effort not to repeat past wrongs, and recognises when the apology is not enough. ${ }^{12}$ The rules outlined by Dr Lerner are general and meant to understand apologies in their simplest form. However, these rules can be used to provide a straightforward lens though which we can analyse all apologies.

\section{The Political Apology}

Although the political apology has a long history, it has become more common since 1945 and the end of the Second World War. ${ }^{13}$ The Institute for the Study of Human Rights (the Institute) has compiled a list of political apologies, beginning in 1077 with the apology of the Holy Roman Emperor Henry IV to Pope Gregory for 'church-state conflicts' and ends in 2016 with an apology made by ISIS to Israel for firing on an Israeli military unit in the Golan Heights. ${ }^{14}$ According to the Institute, after the apology made by the Holy Roman Emperor to the Pope, it took another 340 years before the next political apology, made by way of a proclamation from Queen Margaret I of Denmark. ${ }^{15}$ This apology was made to the peasantry for "the great burden and much toil'"16 caused by the malfeasance of her clerks and herself in 1403. In the period from 1403 to 1911, only 12 recorded political apologies are listed in the study.$^{17}$ From 1910 to 2016, according to the Institute, roughly 640 political apologies were listed. ${ }^{18}$

not silence the other person; (8) Should not make the person making the person apologising 'feel better at the risk of making the hurt party feel worse'; and (9) Recognises that serious harm may take time to restore trust.

12 Ibid.

13 Ruti Teitel, 'The Transitional Apology' in Elazr Barkan and Alexander Karn (eds), Taking Wrongs Seriously, Apologies and Reconciliation (Stanford University Press 2006) 3,101 .

14 Institute for the Study of Human Rights, Columbia University 2016. The list compiled by the Institute describes the selection criteria for inclusion on the list as 'any and all apologies that involve state, nations, or major political groups and actors ...' and did include apologies made by individuals for 'alleged' criminal or personal failings. See Institute for the Study of Human Rights, 'Political Apologies Archive' (Institute for the Study of Human Rights, 2016) <http://www.humanrightscolumbia.org/ahda/politicalapologies $>$ accessed 5 August 2019.

15 Ibid.

16 Ibid.

17 Ibid.

18 Ibid. 
While not a new phenomenon, the frequency of the political apology has increased so significantly over the past 25 years that some refer to this as the 'age of apology'. ${ }^{19}$ As the prevalence of the political apology has increased, so has literature on the topic with, perhaps not surprisingly, some confusion over terminology. The political apology has also been called the state apology, collective apology or reconciliation apology among others. ${ }^{20}$ While each term may be somewhat different in scope, they can be defined by who makes the apology. ${ }^{21}$ In his article on national apologies, Eneko Sanz confirms that the political apology remains somewhat more difficult to describe but "can be loosely considered political if they involve political issues and are delivered by an appropriate political agent'. ${ }^{22}$ Additionally, the political apology can be issued both internally, from the state to its own citizens, or to groups harmed in another state. ${ }^{23}$ Who makes the apology is also important. Political apologies may be made by heads of state on behalf of their country and by 'subgroups" 24 of a country that have the authority to make the apology as nation-state agents. ${ }^{25}$ Apologies are sometimes issued by non-state agents such as 'civil organisations' 26 or religious groups, as can be directed by states at the harmed population of another state to express collective 'regret'. 27

As with personal apologies, the political apology has necessary elements that can help us assess their legitimacy. These elements may include compensation to the wronged party, being responsive to specific requests of the community, and a commitment to changing past hurtful behaviour. ${ }^{28}$ However, as with all types of apologies these components are more than just the sum of their parts. In order to assess the political apology for validity, researchers also consider the

19 Eneko Sanz, 'National Apologies: Mapping the Complexity of Validity' (The Centre for Peace and Conflict Studies, April 2012) <http://www.centrepeaceconflictstudies.org/ publications/browse/national-apologies-mapping-the-complexities-of-validity/> accessed 10 June 2019, pp 3, 7.

20 Ibid., 1, 14. The author also identifies the community-focused apology, the many-tomany apology, the historical apology and the public apology.

21 Ibid., 1, 15.

22 Ibid., 15.

Ibid., 16.

23 Ibid.

24 Ibid., 15-17.

25 Ibid.

26 Ibid.

27 Ibid., 23.

28 Ibid., 26, 27. 
'interconnectedness ${ }^{29}$ of these elements as a way to determine whether it will be deemed a 'true apology' ${ }^{30}$ and perceived as an apology that will serve to move the dialogue with affected groups towards reconciliation. Other theorists contend that given the stakes of the political apology, critical elements must also include 'an official written record' 31 that provides parties an opportunity to assess the value and subsequent attempts to cure made by the state, as well as a measure of ceremony and 'concrete reparation'. ${ }^{22}$ In their article, The Status of State Apologies, authors Gibney and Roxstrom suggest criteria that the apology should be made public, have some element of ceremony attached, should be clear and concise, and state what the apology is for. ${ }^{33}$ The authors assert that justice and consistency are also important elements. ${ }^{34}$ An apology that lacks these essential details and that fails to be responsive to the community voice is defined as a non-apology or quasi-apology and is, therefore, deemed 'fundamentally flawed'. ${ }^{35}$ It is not surprising, therefore, that the political apology is viewed as complex and thus not taken lightly by those states that issue them. ${ }^{36}$

Since the repercussions of political apologies can be so fraught with delicate social and political considerations, the question remains - why do states feel compelled to make them? One theorist suggests that states apologise for three reasons: (1) in order to underscore and validate a change in its own past beliefs and harmful actions stemming from those beliefs; (2) as consideration for using the history of past actions to understand modern disadvantages to groups which it has harmed; and (3) to advance its obligations and define the boundaries of 'membership in the national community'. ${ }^{37}$ Others suggest that the principles underlying the apology are to repair past relationships and to lay the groundwork for future stabilisation and transitional process. ${ }^{38}$ While ostensibly a step forward

29 Ibid., 11.

30 Ibid.

31 Matt James, 'Wrestling with the Past: Apologies, Quasi-Apologies, and Non-Apologies in Canada' in Mark Gibney and others (eds), The Age of Apology: Facing up to the Past (University of Pennsylvania Press 2008) 137, 138.

32 Ibid.

33 Mark Gibney and Eric Roxstrom, 'The Status of State Apologies' (2001) 23(4) HRQ 911, 927-929, 931, 932-933.

34 Ibid., 931. The authors suggest that while financial support may be helpful, it is often much less than what the country spent to perpetrate the wrong in the first place.

35 Sanz (n 20) 11.

36 Ibid.

37 Melissa Nobles, The Politics of Official Apologies (Cambridge University Press 2008) 71,72 .

38 Sanz (n 20) 10. 
in relationship building, viewing the political apology from this perspective is troubling because the political apology emerges from the dominant party and does not consider or address what is important or valuable to the needs of marginalised parties. This, in and of itself, underscores the historic and ongoing imbalance of power between the state and its minority and indigenous populations. ${ }^{39}$

In her book, The Politics of Official Apologies, Melissa Nobles asserts that official apologies serve the function of assessing past acts though a modern lens. ${ }^{40}$ According to Nobles, when coupled with new facts and societal understandings, political apologies can become the cornerstones for moving forward in new relationships. ${ }^{41}$ It is worth noting here that the political apology has become the preferred method chosen by the West to acknowledge past wrongs as opposed to the use of truth commissions. ${ }^{42}$ It is not altogether clear why some states choose the apology over truth and reconciliation. ${ }^{43}$ It may be that where truth and reconciliation has been tried it has not proven to be successful overall in transforming relationships between the state and its citizens in achieving the measure of reconciliation hoped for ${ }^{44}$ Regardless of which process has been employed, there has been a general acknowledgement that states must deal with these past wrongs in order to find a way forward to some measure of societal healing. ${ }^{45}$ How a state chooses to move forward may ultimately prove to be more important than which type of process is chosen. As Professor Corntassel notes, a process that chooses to look only at the wrongs perpetrated and not the underlying relationships that lead to those wrongs, also known as affirmative repair, is inherently misguided by its very nature. ${ }^{46}$ Transformative repair, on the other hand, because its process looks more deeply at the root of the relationship between parties in an effort to transform those relationships, stands a better chance of repairing those historical wrongs. ${ }^{47}$ Corntassel asserts that a critical component must include 'a shared' 48 vision of the future and 'strategies for moving forward

39 Jeff Corntassel and Cindy Holder, 'Who's Sorry Now? Government Apologies, Truth Commissions, and Indigenous Self-Determination in Australia, Canada, Guatemala, and Peru' (2008) 9(4) Hum Rights Rev 465, 466.

40 Nobles, (n 38) 72.

41 Corntassel and Holder (n 40) 466.

42 Ibid.

43 Ibid., 466-467.

44 Ibid., 466-468.

45 Ibid.

46 Ibid.

47 Ibid.

48 Ibid., 469. 
collectively' 49 as a 'means to decolonise' both past and present relationships. ${ }^{50}$ However, he also contends that even with all of the above, tangible reconciliation may be still unattainable if states are unwilling to 'go beyond ideals of national unity and modernisation'. ${ }^{51}$

Many nations have issued apology like statements to their indigenous populations since the Declaration was approved in 2007. ${ }^{52}$ However, the usefulness of these statements in light of general inaction on the part of states to implement the Declaration remains in question. Indigenous peoples continue to face significant hurdles in achieving the human rights expressed in the Declaration. This is in spite of state endorsement of the aspirations and goals expressed following the Declaration's adoption and whether or not an apology was ever issued. Even if statements of support do rise to the level of a true apology, the question remains whether apologies in this context work as they are meant to as the fundamental key to heal, build and maintain key relationships where the history of oppression has been deep and longstanding.

\section{APOLOGY OR EQUIVOCATION?}

\section{Australia}

In April 2009, 18 months after the Declaration was adopted, the government of Australia, under new leadership, announced that it had changed its opposition and formally endorsed the Declaration. ${ }^{53}$ In affirming the aspirations of the Declaration, the Australian government recognised the 'flawed policies' ${ }^{54}$ of the past and considered the adoption of the Declaration as a 're-setting' 55 of the 'relationship between Indigenous and non-Indigenous Australians. ${ }^{56}$ In spite of this endorsement, the statement did not contain an apology to aboriginal Australians for Australia's past actions.

49 Ibid.

50 Ibid.

51 Ibid.

52 Sheryl Lightfoot, 'Settler-State Apologies to Indigenous Peoples: A Normative Framework and Comparative Assessment' (2015) 2(1) University of Minnesota Press 15.

53 Emma Rogers, 'Australia Adopts UN Indigenous Declaration' (ABC News, 2009) <https://wwww.abc.net.au/news/2009-04-03/aust-adopts-un-indigenousdeclaration/1640444> accessed 1 December 2018.

54 Ibid.

55 Ibid.

56 Ibid. 
The statement made in support of the Declaration was in stark contrast to the apology made 13 months earlier by Prime Minister Kevin Rudd for the mistreatment of children and families of the Stolen Generation. In that apology, PM Rudd apologised to the Stolen Generation by acknowledging and reflecting on past mistreatment and made clear expressions of regret for the pain and suffering caused by policies and actions of the Australian government. ${ }^{57}$ This apology does have its own shortcomings and was critiqued as falling short by Melissa Cuthbert because it was couched in general terms and past wrongs while ignoring continuing and ongoing oppression of Australia's indigenous population. ${ }^{58}$

Despite the Australian Government showing in the Lost Generations apology that it understood at least some of the elements necessary to craft a true apology, its endorsement of the Declaration falls flat in that it contains none of the fundamental elements required. The subsequent result of the non-apology by the Australian government is a lack of promised change in the relationship and a failure to re-set the relationship as promised. One example is evidenced by the recommendation and proposal of the Expert Panel on Recognizing Aboriginal Rights and Torres Strait Islander Peoples. Their report recommended that a prohibition on racial discrimination be housed in Australia's constitution..$^{59}$ This proposal was ultimately opposed by both conservatives and a number of indigenous leaders for different reasons. ${ }^{60}$ Conservatives opposed "entrenching rights in the Constitution' ${ }^{61}$ and indigenous leaders were not convinced that language would by itself present any real benefit to indigenous peoples. ${ }^{62}$

Given that the Australian endorsement of the Declaration was not an apology in the first instance, it is also not surprising that the Report of the Special Rapporteur on the Rights of Indigenous Peoples, Victoria Tauli-Corpuz, published

57 Prime Minister Kevin Rudd MP, 'Apology to Australia's Indigenous Peoples' (Australian Government, February 2008) <https://www.australia.gov.au/about-australia/ our-country/our-people/apology-to-australias-indigenous-peoples $>$ accessed 1 December 2018.

58 Denise Cuthbert, 'Forced Child Removal and the Politics of National Apologies in Australia' (2013) 37 Am Indian Q 178, 184.

59 Commonwealth of Australia, 'Recognising Aboriginal and Torres Strait Islander Peoples in the Constitution: Report of the Expert Panel' (Commonwealth of Australia, January 2012) <https://www.pmc.gov.au/sites/default/files/publications/RecognisingAboriginal-and-Torres-Strait-Islander-Peoples-in-the-constitution-report-of-the-expertpanel_0.pdf $>$ accessed 1 December 2018.

60 Darryl Cronin, 'Trapped by History: Democracy, Human Rights and Justice for Indigenous People in Australia' (2017) 23(2) Aust J of Hum Rights 220, 234.

61 Ibid., 234.

62 Ibid., 235. 
in August 2017, found that existing policies of the government of Australia did not respect indigenous peoples right to self-determination and 'failed to deliver' ${ }^{63}$ in such critical areas as health, education, housing, incarceration and violence against women. ${ }^{64}$ While Tauli-Corpuz' report did acknowledge that the government had implemented a number of policies addressing indigenous matters, her criticisms focused on the failure of the government to meaningfully 'respect the rights to self-determination' 65 and the lack of 'full and effective' ${ }^{66}$ participation of Aboriginal and Torres Strait Islanders in that decision making. ${ }^{67}$ As such, Ms Tauli-Corpuz called for a 'comprehensive revision' ${ }^{68}$ of those policies affecting aboriginal Australians and underlined the need to make it a 'national priority'. ${ }^{69}$ The report made 31 specific recommendations for change to Australian government policies ranging from changes to the institutional framework of existing policies to investing in community-led child-family programs in order to minimise the removal of aboriginal children from their families and communities. ${ }^{70}$ The depth and breadth of these recommendations clearly illustrate how far the Australian Government has yet to go in order to repair relationships with its indigenous citizens. They also emphasise how the non-apology contained in the original endorsement failed to create the necessary framework required to begin implementing the Declaration.

\section{Canada}

On 12 November 2010, the Canadian government issued a statement supporting the Declaration but was quick to assert that the Declaration 'does not reflect customary international law nor change Canadian laws. ${ }^{71}$ While recognising its

63 United Nations Human Rights Office of the Commissioner, 'Report of the Special Rapporteur on the Rights of Indigenous Peoples on Her Visit to Australia' (OHCHR, 8 August 2017) <http://ap.ohchr.org/documents/dpage_e.aspx?si=A/HRC/36/46/Add.2, para 104.

64 Ibid.

65 Ibid., para 36.

66 Ibid.

67 Ibid.

68 Ibid., 104.

${ }^{69}$ Ibid.

70 Ibid., paras 107 (a)-(f), 108 (a)-(g), 109 (a)-(e), 110 (a)-(c), 111 (a)-(c), 112 (a)-(b), 113, (a)-(m), 114, (a)-(c), 115, 116, 117, 118, (a)-(c).

${ }^{71}$ Cultural Survival, 'Canada Endorses the UN Declaration on the Rights of Indigenous Peoples' (Cultural Survival, November 2010) <https://www.culturalsurvival.org/news/ canada-endorses-un-declaration-rights-indigenous-peoples> accessed 10 June 2019. 
aspirational language, Canada's statement of support for the Declaration did not make any effort to acknowledge present or historical wrongs to the indigenous peoples of Canada. Instead, their statement focused on the "exemplary progress' 72 in the relationship with the indigenous nations of Canada and their leadership in protecting indigenous rights. ${ }^{73}$ Although not altogether surprising, given the Harper government's active lobbying against the declaration in the years just prior to its adoption, their statement made no declaration of regret or apology. ${ }^{74}$ Not only did the Harper government not apologise, they have been criticised for interpreting the Declaration so narrowly as to undermine its ability to make even the most basic changes in the laws or policies governing indigenous rights in Canada in the years following the endorsement. ${ }^{75}$

In a joint statement released immediately following Canada's statement of endorsement, more than 25 organisations supporting indigenous rights in Canada, voiced strong criticism of the government's position. Citing specifically that Canada's position that the Declaration 'does not reflect customary international ${ }^{76}$ law', and as being 'manifestly untenable ${ }^{77}$ pursuant to the position of the UN Special Rapporteur on the rights of Indigenous People. ${ }^{78}$ The joint statement was pointed in its critique that the Declaration was merely 'aspirational' 79 and argued that it belied common sense to assert that Canada's obligation to support the Declaration existed only as long as it comported with existing 'national law and policies'. ${ }^{80}$ The statement further called on the government to make tangible commitments to build on the existing relationship with indigenous nations based on 'partnership, equality and justice'. 81

It was not until May 2016, nearly 10 years after the adoption of the Declaration, that Canada finally dropped its objector status and committed to implementing the

72 Ibid.

73 Ibid.

74 Sheryl Lightfoot, 'On the UN Declaration on the Rights of Indigenous Peoples' (Faculty of Arts UBC, June 2017) <https://www.arts.Ubs,ca/Sheryl-lightfoot-on-theun-declarations-on-the-rights-of indigenous-peoples/> accessed 22 April 2019.

75 Ibid.

76 Cultural Survival, 'Joint Statement in Response to Canada's Endorsement of the UN Declaration on the Rights of Indigenous Peoples' (Cultural Survival, November 2010) $<$ https://www.culturalsurvival.org/news/joint-statement-response-canadas-endorsementun-declaration-rights-indigenous-peoples> accessed 1 December 2018.

77 Ibid.

78 Ibid.

79 Ibid.

80 Ibid.

81 Ibid. 
Declaration within the framework of the Canadian Constitution. ${ }^{82}$ The government then began the process of meeting with First Nations, Inuit and Metis peoples in order to identify priorities for moving forward ${ }^{83}$ Nevertheless, criticism of the implementation process continues over the interpretation of specific language contained in the Declaration, with it being described as "unworkables4, and a 'political distraction' ${ }^{95}$ by members of the government. ${ }^{86}$ Regardless of the political pushback, Indigenous Affairs Minister, Carolyn Bennett, affirmed Canada's intention to implement the Declaration as a full supporter 'without qualification'. ${ }^{87}$

Regardless of Canada's official change in position, the uncertainty over the impact of implementation of the Declaration on existing and future Canadian legislation remains an unanswered and ongoing question.

\section{New Zealand}

In April 2010, two and a half years after the Declaration was approved, New Zealand issued its endorsement. ${ }^{88}$ The announcement was made by Dr Pita Sharples at the annual meeting of the UN Forum on Indigenous Issues and

82 Tim Fontaine, 'Canada Removing Objector Status to UN Declaration on the Rights of Indigenous Peoples' (CBC News, 8 May 2016) <https://www.cbc.ca/news/indigenous/ canada-position-un-declaration-indigenous-peoples-1.3572777> accessed 6 August 2019.

${ }^{83}$ Brandi Morin, 'Where Does Canada Sit 10 Years after the UN Declaration on the Rights of Indigenous Peoples?' (CBC News, 13 September 2017) <https://cbc.ca/news/ inidigenous/where-does-canada-sit-10-years-after-undrip-1.4288480> accessed 10 June 2019.

${ }^{84}$ APTN National News, 'Justice Minister Jody-Wilson-Raybould Says Adopting the UNDRIP into Canadian Law "unworkable" (APTN National News, 12 July 2016) $<$ https://aptnnews.ca/2016/07/12/justice-minister-jody-wilson-raybould-says-adoptingundrip-into-canadian-law-unworkable/> accessed 16 January 2019.

85 Ibid.

86 Ibid.

${ }^{87}$ Tim Fontaine, 'Senator Murray Sinclair on Canada's Change of Stance on United Nations Indigenous Rights Declaration' (CBC News, 10 May 2016) <https://www.cbc.ca/ news/indigenous/canada-adopting-implementing-un-rights-declaration-1.3575272> accessed 1 December 2018.

${ }^{88}$ New Zealand Parliament, 'Ministerial Statements - UN Declaration on the Rights of Indigenous Peoples - Government Support' (parliament.nz, 20 April 2010) <https://www. parliament.nz/en/pb/hansard-debates/rhr/document/49HansD_20100420_00000071/ ministerial-statements-un-declaration-on-the-rights-of-indigenous-peoples $>$ accessed 6 August 2019. 
expressly conveyed that New Zealand had changed its original position on the Declaration and affirmed those rights and aspirations declared therein. ${ }^{89}$ In his statement, Minister Sharples referred to the historic relationship between Maori peoples and the Crown as defined in the Treaty of Waitangi, recognised the Maori as the original inhabitants of New Zealand, that their customs and traditions should be reflected in the laws of New Zealand, and that the Maori suffered historic injustice with respect to land and settlements. ${ }^{90}$ However, the address also emphasised that further settlements needed to be fair to 'everyone' and redress for past wrongs would be constrained by what the country could afford to pay. ${ }^{91}$

Assessing the minister's statement through the lens of political apology theory, the statement falls short of the necessary elements in what is defined as a true apology as it lacks the acknowledgement of responsibility. Nor does the statement of support for the Declaration make a clear expression of regret. It is not surprising, therefore, that there has been criticism of New Zealand's conditional and aspirational acceptance of the Declaration. ${ }^{92}$ In July 2018, Mr Sharples, in a reflective essay, himself asks the question, 'Was It Worth It?'. ${ }^{33}$ He speaks of the lip service that is given to the need for change for the Maori and underscores the need for the Maori people to step up and 'take control of our lives and our destiny ... ${ }^{94}$ in order to ensure the survival of his people. ${ }^{95}$

In spite of Sharple's critique, the Human Rights Council Working Group on the Universal Period Review in November 2013 issued an overall positive review of New Zealand's continued dialogue on broad human rights issues. ${ }^{96}$ However, it recommended ongoing dialogue with the Maori on such important issues as strengthening historical land claims, improving educational priorities and addressing institutional racism. ${ }^{97}$ It is interesting that of the four endorsements of

\footnotetext{
89 Ibid.

90 Ibid.

91 Ibid.

92 Tracey Watkins, 'NZ Does a U-Turn on Rights Charter' (Stuff.co.nz, 24 April 2010) $<$ https://stuffco.nz.national/politics/3599153/NZ-does-U-turn-on-rights/charter> accessed 5 November 2018.
}

93 Pita Sharples, 'Was It Worth It?' (The University of Auckland, 16 July 2018) <https:// www.thebigq.org/2018/07/16/was-it-worth-it-pita-sharples-reflects-on-the-un-declarationof-indigenous-rights/> accessed 5 November 2018.

94 Ibid., 8.

95 Ibid.

96 Human Rights Council, 'Report of the Working Group on the Universal Periodic Review' (United Nations Human Rights Office of the High Commissioner, 8 November 2013) <https://undocs.org/A/HRC/WG.6/18/NZL/1> accessed 6 August 2019, paras 1-2.

97 Ibid., para 4. 
the Declaration by the formerly opposing states, Mr Sharple's statement came the closest to a formal apology. Nevertheless, the extent that apologies to indigenous peoples have made any meaningful difference in the quality of their lives in the decade since its approval remains contested.

\section{United States}

On 16 December 2016, the United States, the last of the four states initially opposed to the Declaration, finally announced its support for it at a White House gathering that included members of the then 565 federally recognised Indian Tribes. ${ }^{98}$ President Obama affirmed the aspirations of the Declaration and recognised the need to respect the cultures and institutions of native peoples and underscored the need to match words with actions. ${ }^{99}$

Immediately following the announcement by the president, the Office of the Special Representative for Global Intergovernmental Affairs released a set of initiatives outlining the United States' commitment to address a number of issues facing Native Americans. ${ }^{100}$ Importantly, prior to its change of position on the Declaration, US agencies conducted a series of consultations with tribal leaders, as well as providing an open comment period that solicited over 3,000 written comments. ${ }^{101}$ The result was a focus on five specific areas in line with those rights encompassed in the Declaration. These included increased recognition and strengthening of the government-to-government relationship between the US government and tribal nations, the protection of tribal lands, the environment and access to traditional lands and natural resources in which tribes have an interest. The list also included addressing the health needs and gaps in health care delivery to tribal people, promoting economic development and protection of Native American cultures. ${ }^{102}$

\footnotetext{
98 Valerie Richardson, 'Obama Adopts U.N. Manifesto on Rights of Indigenous Peoples' (Washington Post, 16 December 2010) <https://www.washingtontimes.com/news/2010/ dec/16/obama-adopts-un-manifesto-on-rights-of-indigenous-/> accessed 10 June 2019. The number of federally recognised Native American Tribes has increased to 573 since the adoption of the UNDRIP by the United States.

99 Ibid.

100 Office of the Special Representative for Global Intergovernmental Affairs, 'Announcement of U.S. Support for the United Nations Declaration on the Rights of Indigenous Peoples' (U.S. Department of State, 12 January 2011) <https://2009-2017.state. gov/s/srgia/154553.htm > accessed 10 June 2019, pp. 1-15.

101 Ibid., 2.

102 Ibid., 1-15.
} 
These initiatives, however, were not new policies nor were any legislative changes made as a result of support for the Declaration. They were, in fact, based on Nixon era policies put in place to encourage greater tribal autonomy and decision making. ${ }^{103}$ Nevertheless, the statement of initiatives in conjunction with calls to further support self-determination, the commitment to engage in collaborative tribal and government agency policy development, along with the acknowledgement that tribal people have been significantly marginalised by historic policies and actions of the US government was significant.

President Obama's endorsement of the Declaration, while welcomed by tribal nations and well-meaning was not an apology. ${ }^{104}$ It was simply a statement recognising the aspirations contained in the Declaration. ${ }^{105}$ The formal apology to Native Peoples was made almost two years earlier, on 6 January 2009, without fanfare, hidden on page 45 of a Department of Defense Appropriations Bill in the First Session of the $111^{\text {th }}$ Congress. ${ }^{106}$ The apology itself (in full below) clearly ticks some of the boxes of an effective political apology as discussed above, but leaves out other important components and fails to deliver on others. For instance, is it an apology if no one hears it, being buried as it was in the appropriations bill? Additionally, where is the ceremony or public expression of regret? Where is the explanation of why the US government acted the way it did in relation to the individuals and tribal nations that it harmed? The non-apology issued by the US ultimately has had very little impact on the lives and well-being of tribal people.

Sec. 8113.

a. Acknowledgement and Apology. The United States, acting through Congress

1. recognises the special legal and political relationship Indian tribes have with the United States and the solemn covenant with the land we share;

103 On the occasion marking the $45^{\text {th }}$ anniversary of President Richard Nixon's Message to Congress on Indian Affairs which is seen as marking the beginning of the SelfDetermination Movement. See LaDonna Harris, 'Institutionalizing the Native American Self-Determination Movement' (Indian Country Today, 8 July 2015) <https://newsmaven. io/indiancountrytoday/archive/institutionalizing-the-native-american-self-determinationmovement-DKQEQCMxpEuuGbV-c2zL_A/> accessed 10 June 2019, pp 1-13.

104 Ginny Underwood, 'Obama Endorses US Endorsement of UNDRIP' (YouTube, 16 December 2010) <https://www.youtube.com/watch?v=YMv2xiqaWYc> accessed 22 April 2019.

105 Ibid.

106 Congress.gov, 'H.R. 3326 - Department of Defense Appropriation Act, 2010' (Congress.gov, 2009-2010) <https://www.congress.gov/bill/111th-congress/housebill/3326?s=1\&r=12> accessed 10 June 2019. 
2. commends and honours Native Peoples for the thousands of years that they have stewarded and protected this land;

3. recognises that there have been years of official depredations, ill-conceived policies, and the breaking of covenants by the Federal Government regarding Indian tribes;

4. apologises on behalf of the people of the United States to all Native Peoples for the many instances of violence, maltreatment, and neglect inflicted on Native Peoples by citizens of the United States;

5. expresses its regret for the ramifications of former wrongs and its commitment to build on the positive relationships of the past and present to move towards a brighter future where all the people of this land live reconciled as brothers and sisters, and harmoniously steward and protect this land together;

6. urges the President to acknowledge the wrongs of the United States against Indian tribes in the history of the United States in order to bring healing to this land; and

7. commends the State governments that have begun reconciliation efforts with recognised Indian tribes located in their boundaries and encourages all State governments similarly to work towards reconciling relationships with Indian tribes within their boundaries.

b. Disclaimer. Nothing in this section -

1. authorises or supports any claim against the United States; or

2. serves as a settlement of any claim against the United States. ${ }^{107}$

The disclaimers tacked on to this hidden apology also apply to President Obama's endorsement of the Declaration. The bill specifically states that the apology does not support any claim against the United States, a provision which clearly undercuts any real desire to pave a path forward. Similarly, the US announcement documenting its support for the Declaration specifically asserts that it is neither 'legally binding or a statement of current international law'.108 Furthermore, the statement acknowledges that consultation with tribes over matters affecting tribal interests is important, but agreement with tribes on those interests was not required for final decision making. ${ }^{109}$ This, of course, gives with

\footnotetext{
107 Ibid.

108 Office of the Special Representative for Global Intergovernmental Affairs (n 101) $1-15$.

109 Cultural Survival, 'Victory: U.S. Endorses the UN Declaration on the Rights of Indigenous Peoples' (Cultural Survival, 2019) <www.culturalsurvival.org/news/victoryus-endorses-un-declaration-rights-indigenous-peoples $>$ accessed 27 November 2018.
} 
the one hand and takes away, or at least preserves the status quo, with the other. Given that the status quo is replete with historical wrongs that have disadvantaged Native Peoples for generations it is not surprising that the effect of the statement of support for the Declaration on the part of the United States has been ineffectual at best.

\section{CONCLUSION}

Apologies, whether interpersonal or at the state level, are important. How to convey true regret for past actions is vital for all relationships. Equally important is what happens after an apology is made. It makes sense, therefore, that researchers have devoted attention to what makes a true political apology, to determine what essential details that they should contain, and what should be left out. If we are, as the literature contends, in the age of apology, states must undertake to take their apologies seriously as a critical step towards healing the wounds inflicted in their name.

The Declaration was an attempt to define a set of individual and collective rights of indigenous peoples and nations around the globe. Even though many human rights were recognised after the Second World War, it took another half a century for the rights of indigenous peoples to have merit in their own right. It is telling indeed that only four nations objected to the rights contained in the Declaration and refused to recognise those rights. It is significant, as well, that all four nations elected to ignore established political apology considerations when they finally made statements of support recognising those rights. Not one of the four made a true apology in their endorsement of the Declaration. This has significance as we assess what progress has been made in the well-being of indigenous peoples and indigenous nations and as we embark on the second decade of this historic international instrument.

Even as indigenous peoples are encouraged to use the Declaration to advocate for those rights contained in it, states must themselves step up to implement the protections and reforms enshrined in the Declaration. The endorsements by Australia, Canada, New Zealand and the United States, following the adoption of the Declaration were non-apologies. Whether those non-apologies were intentional or not, each must develop meaningful strategies for implementing the Declaration and beginning the process of making concrete legislative changes in support of their indigenous citizens. Only then can those relationships begin the process of healing after centuries of past wrongs. 